\title{
Mutants of Escherichia coli K12 Accumulating Porphobilinogen: a New Locus, hemC
}

\author{
By MALCOLM L. MCCONVILLE AND H. P. CHARLES \\ Department of Microbiology, The University, Reading $R G 15 A Q$
}

(Received 28 July 1978)

\begin{abstract}
Mutants of Escherichia coli $\mathrm{K} 12$ which accumulated the haem precursor porphobilinogen are described. The mutants grew very slowly on carbon and energy sources which K12 uses only oxidatively, and they had low catalase activities, suggesting that they were deficient in haem. Extracts had one-tenth of the parental activity of the enzyme porphobilinogen deaminase. In transduction, the mutation mapped close to genes ilvD and metE at minute 84 . The gene was tentatively identified as hemC, coding for porphobilinogen deaminase. The gene symbol hemC replaces the earlier and temporary symbol popE.
\end{abstract}

\section{INTRODUCTION}

Escherichia coli $\mathrm{K} 12$ is impermeable to haemin and so the genetics of haem biosynthesis has not been open to ordinary methods of analysis. To obtain mutants with defects in intermediate reactions of porphyrin biosynthesis, Cox \& Charles (1973) used a strain carrying mutation popA1. The strain gave reddish-brown colonies because the bacteria accumulated protoporphyrin IX. From the mutant, secondary mutants were isolated which grew as small white or pink colonies. The new mutations were given the temporary symbol sec and an isolation number, e.g. sec-20. Secondary mutants contained less cytochromes and catalase than the parent strain and they grew very slowly on non-fermentable carbon and energy sources. Their growth was not stimulated by haemin and porphyrins. Some mutants accumulated large quantities of haem precursors; thus a strain carrying mutations popA1 sec-20 accumulated coproporphyrin III and possessed one-fifth of the coproporphyrin oxidase activity of strain popAl (Cox, 1973). A strain carrying mutations popA1 sec-130 accumulated 5-aminolaevulinate and lacked detectable activity of 5-aminolaevulinate dehydratase (Powell, 1975; Powell et al., 1973). Mutants accumulating porphobilinogen or uroporphyrin were not obtained, probably because too few mutants were examined. In the experiments described in this paper a successful search was made for mutants which accumulated porphobilinogen. One of the mutants, carrying mutation sec-200, was briefly mentioned by Powell et al. (1973). The symbol sec-200 is now replaced by the symbol hemC200, in accordance with the suggestion of Săsărman et al. (1976).

\section{METHODS}

The materials, media, cultures and methods were, in general, as described by Cox \& Charles (1973). Glucose minimal medium (GM) was the medium of Vogel \& Bonner (1956) and contained ( $\left.\mathrm{g} \mathrm{I}^{-1}\right)$ : glucose, $5 ; \mathrm{MgSO}_{4} .7 \mathrm{H}_{2} \mathrm{O}, 0.25 ;$ citric acid. $\mathrm{H}_{2} \mathrm{O}, 2 \cdot 5 ; \mathrm{K}_{2} \mathrm{HPO}_{4}, 12 \cdot 5 ; \mathrm{NH}_{4} \mathrm{NaHPO}_{4} .4 \mathrm{H}_{2} \mathrm{O}, 4 \cdot 37$. Thiamin. $\mathrm{HCl}$ $\left(0.8 \mathrm{mg} \mathrm{1}^{-1}\right)$ was also added because many strains carried a thi mutation. Glucose minimal agar (GMA) was GM containing Difco Bacto-agar $\left(13 \mathrm{~g} \mathrm{l}^{-1}\right)$. Complete medium contained $\left(\mathrm{g}^{-1}\right)$ : Tryptone (Oxoid), 10; yeast extract (Difco), $5 ; \mathrm{K}_{2} \mathrm{HPO}_{4}, 3 ; \mathrm{KH}_{2} \mathrm{PO}_{4}, 1$; glucose, 5. Phage P1kc was used in transduction experiments; the adsorption time was $12 \mathrm{~min}$. The bacterial strains are shown in Table 1 . Gene symbols and references to the linkage map follow Bachmann et al. (1976).

0022-1287/79/0000-8291 \$02.00 (C) 1979 SGM 


\section{Table 1. Strains of Escherichia coli $\mathrm{K} 12$}

Strain

$\begin{array}{ll}\text { AB1621 } & F^{-} \\ \text {POPA1 } & F^{-}\end{array}$

SEC200 F $\mathrm{F}^{-}$

$\mathrm{AB3509} \mathrm{F}^{-}$

MLM200

MLM509

AB312

AB2575

AT716
Genotype or description

ara-14 tfrA lac Y1 tsx-57 galK2 rpsL $x y l-5$ mtl-1 thi-1 $\lambda^{-}$

The original pop $A 1$ mutant of $\mathrm{AB} 1621$; allele pop $A 1$ is now designated hemG1 (Săsărman et al., 1975)

POPA1 carrying mutation sec-200; allele sec-200 is now designated hemC200

proA2 tsx-3 galK2 trp-3 his-4 rel-1 malA1 mtl-1 ilvDI44 metE46 argH1 thi-1 $\lambda^{\mathrm{R}} \lambda-$ sup-16? sup-38 or sup-48

hemG1 $x y l^{+}$hemC200: a $x y l^{+}$transconjugant from conjugation between AB2575 and SEC200; other markers not tested

trp ${ }^{+}$ilv $D$ metE: a trp ${ }^{+}$transconjugant from conjugation between AB2575 and AB3509; other markers not tested

Hfr thr leu rpsL

Hfr ilv thiA tsx (Hfr Hayes type)

Hfr $\quad$ rel-1 rbsP thi-1 $\lambda^{-}$
Reference or source

Adelberg et al. (1965)

Cox \& Charles (1973)

Powell et al. (1973)

Wechsler \& Adelberg (1969)

Taylor \& Adelberg (1960)

E. A. Adelberg

B. J. Bachmann

Assay of 5-aminolaevulinate synthase (EC 2.3.1.37). The method of Burnham \& Lascelles (1963) was used. The reaction mixture contained, in $2 \mathrm{ml}$ : glycine, $100 \mu \mathrm{mol}$; sodium succinate, $100 \mu \mathrm{mol}$; coenzyme A, $0.58 \mu \mathrm{mol}$; pyridoxal phosphate, $0.25 \mu \mathrm{mol}$; ATP, $7.5 \mu \mathrm{mol} ; \mathrm{MgCl}_{2}, 10 \mu \mathrm{mol}$; EDTA, $1.0 \mu \mathrm{mol}$; glutathione, $1.5 \mu \mathrm{mol}$; Tris (pH 7.8), $50 \mu \mathrm{mol}$; bacterial extract, $1 \mathrm{ml}$ (15 to $20 \mathrm{mg}$ protein). The reaction was stopped by adding $1 \mathrm{ml}$ trichloroacetic acid $(10 \%, \mathrm{w} / \mathrm{v})$. The product of the reaction, 5-aminolaevulinic acid (5-ALA), was assayed by the method of Gibson et al. (1958).

Assay of 5-aminolaevulinate dehydratase (EC 4.2.1.24). The method of Burnham \& Lascelles (1963) and Cox (1973) was used. The reaction mixture contained, in $2 \mathrm{ml}: 5$-ALA, $10 \mu \mathrm{mol} ; \mathrm{MgCl}_{2}, 5 \mu \mathrm{mol}$; L-cysteine, $25 \mu \mathrm{mol}$; potassium phosphate buffer (pH 7.5), $125 \mu \mathrm{mol}$; bacterial extract, $1 \mathrm{ml}$ (15 to $20 \mathrm{mg}$ protein). The reaction was started by adding 5-ALA. It was stopped in one tube immediately, and in a second after $1 \mathrm{~h}$ at $37^{\circ} \mathrm{C}$ by adding $1 \mathrm{ml}$ trichloroacetic acid $(10 \%$, w/v). Controls were (a) reaction mixture without extract and (b) reaction mixture without 5-ALA. Precipitated protein was removed and the supernatant liquid was diluted and assayed for porphobilinogen by the method of Mauzerall \& Granick (1956), using modified Ehrlich's reagent and measuring the absorbance at $555 \mathrm{~nm}$.

Assay of porphobilinogen deaminase (EC 4.3.1.8). The assay was based on the method of Bogorad (1958). The reaction mixture contained, in $2 \mathrm{ml}$ : porphobilinogen (PBG; Sigma), $400 \mathrm{nmol}$; Tris buffer (pH 8.2), $125 \mu \mathrm{mol}$; extract, $1 \mathrm{ml}$ (15 to $20 \mathrm{mg}$ protein). The reaction was started by adding PBG. It was stopped in one tube immediately, and in a second after $1 \mathrm{~h}$ at $37^{\circ} \mathrm{C}$ by adding trichloroacetic acid $(10 \%, \mathrm{w} / \mathrm{v})$. Protein was removed and the supernatant medium was assayed for PBG. Controls were (a) reaction mixture without extract and (b) reaction mixture without PBG.

Assay of ability to form porphyrins from PBG. Cox \& Charles (1973) and Powell (1975) showed that crude extracts gave good conversion of 5-ALA to coproporphyrin III. Because pure substrates of some intermediate reactions were not available, the overall formation of porphyrins from 5-ALA or PBG offered a convenient method of testing for gross defects in intermediate reactions. The assay mixture contained, in $2 \mathrm{ml}$ : PBG, $400 \mathrm{nmol}$; phosphate buffer (pH 7.5), $100 \mu \mathrm{mol}$; extract, $1 \mathrm{ml}$ (15 to $20 \mathrm{mg}$ protein). The mixture was incubated in the dark at $37^{\circ} \mathrm{C}$ with shaking. The controls were (a) buffer plus PBG, (b) buffer plus extract and (c) buffer plus PBG plus extract heated to $100^{\circ} \mathrm{C}$ for $5 \mathrm{~min}$. The reaction was stopped after $200 \mathrm{~min}$ by adding $1 \mathrm{ml}$ trichloroacetic acid $(10 \%, \mathrm{w} / \mathrm{v})$ and the mixtures were aerated in daylight with a vortex mixer to convert porphyrinogens to porphyrins. Porphyrins were extracted and esterified by the method of Falk (1964), and were then separated as methyl esters on silica gel plates (Doss \& Philipp-Dormston, 1971) and assayed spectrophotometrically using the millimolar absorption coefficients of Falk (1964).

Catalase activity. This was measured by the method of Herbert (1955). Volumes (5 ml) of a solution of hydrogen peroxide $(0.01 \mathrm{M})$ in phosphate buffer $(0.01 \mathrm{M}, \mathrm{pH} 6.8)$ were pipetted into five test tubes incubated at $25^{\circ} \mathrm{C} ; 1 \mathrm{ml}$ bacterial suspension was added to each of four tubes and the reactions were stopped after $15,30,45$ and $60 \mathrm{~s}$, respectively, by adding $1 \mathrm{ml}$ sulphuric acid $(2.0 \mathrm{M})$; sulphuric acid was added to the fifth tube before the bacterial suspension. The amount of peroxide remaining in each tube was assayed by adding $0.5 \mathrm{ml}$ potassium iodide $(10 \%, \mathrm{w} / \mathrm{v})$ and one drop of ammonium molybdate $(1 \%$, w/v) and, after $3 \mathrm{~min}$, titrating the liberated iodine with sodium thiosulphate $(0.02 \mathrm{M})$ in the presence of starch solution as 
indicator. The velocity constant, $K_{\mathrm{obs}}$, for each of the four reaction times was calculated using the formula $K_{\text {obs }}=(1 / t) \log _{\mathrm{e}}\left(S_{0} / S\right)$ (in $\mathrm{s}^{-1}$ ), where $S_{0}$ and $S$ were the concentrations of peroxide at times 0 and $t$, respectively. The specific catalase activity, $K$, of the intact bacteria was calculated from $K=K_{\text {obs }} / c$, where $K_{\text {obs }}$ was the mean of the experimental values obtained over the four time intervals and $c$ was the dry weight (in $\mathrm{mg}$ ) of the bacterial suspension divided by the volume of the assay mixture $(6 \mathrm{ml})$. For catalase assay, bacteria were grown for $17 \mathrm{~h}$ in GM, washed and resuspended in phosphate buffer $(0.01 \mathrm{M}, \mathrm{pH} \mathrm{6.8)}$ to an approximate concentration of $200 \mathrm{mg}$ wet $\mathrm{wt} \mathrm{ml}^{-1}$.

Preparation of pure samples of the pyrrole (PBG) accumulated by the mutants and assay of $P B G$. The method of Cookson \& Rimington (1954) was used, which makes use of the fact that PBG forms a mercuric salt which is insoluble in water and decomposed by $\mathrm{H}_{2} \mathrm{~S}$. Bacteria were grown in $800 \mathrm{ml} \mathrm{GM}$, with shaking for $24 \mathrm{~h}$. The $\mathrm{pH}$ value of the supernatant medium was adjusted to 4.0 with glacial acetic acid, and then a solution of mercuric acetate $(15 \%, \mathrm{w} / \mathrm{v})$ was added until the medium ceased to give a pink colour with Ehrlich's reagent. The precipitate was washed with mercuric acetate $(1 \%, \mathrm{w} / \mathrm{v})$, resuspended in $3 \mathrm{ml}$ water and decomposed with $\mathrm{H}_{2} \mathrm{~S}$. The mercuric sulphide was removed by centrifugation and $\mathrm{H}_{2} \mathrm{~S}$ was removed by passing air through the solution. The solution was then treated successively with lead acetate $(10 \%, \mathrm{w} / \mathrm{v})$ and silver nitrate $(20 \%, \mathrm{w} / \mathrm{v})$ to remove dipyrrolic and tetrapyrrolic substances; the precipitates were discarded. To the filtrate an excess of mercuric acetate $(15 \%, \mathrm{w} / \mathrm{v})$ was added. The precipitate was collected by centrifugation and decomposed without addition of water by passing $\mathrm{H}_{2} \mathrm{~S}$ into the paste and stirring with the gassing tube. The mercuric sulphide was removed by centrifugation and air was passed through the solution to remove $\mathrm{H}_{2} \mathrm{~S}$.

PBG was assayed by the method of Mauzerall \& Granick (1956). Equal volumes of Ehrlich's reagent were added to serial dilutions of the preparations, and after $15 \mathrm{~min}$ the absorbance at $555 \mathrm{~nm}$ was measured using a Perkin Elmer Hitachi 124 automatic scanning spectrophotometer. The reference cuvette contained equal volumes of Ehrlich's reagent and water. The concentration of PBG was calculated using the absorption coefficient $\epsilon_{\mathrm{mM}}=61$ (Mauzerall \& Granick, 1956).

\section{RESULTS}

\section{Isolation of mutants which accumulated porphobilinogen}

Strain POPA1, carrying mutation popA1 (Cox \& Charles, 1973) now called hemG1 (Săsărman et al., 1975), was treated with $N$-methyl- $N^{\prime}$-nitro- $N$-nitrosoguanidine $\left(30 \mathrm{mg} \mathrm{1^{-1 } )}\right.$ for $20 \mathrm{~min}$, washed, incubated in complete medium for $14 \mathrm{~h}$ and plated on GMA. Amongst the reddish-brown colonies of $5 \mathrm{~mm}$ diameter were occasional white colonies of $1 \mathrm{~mm}$ or less; 300 of these were transferred to $3 \mathrm{ml}$ volumes of GM. After $48 \mathrm{~h}$ incubation, without shaking, the supernatant media were tested with Erhlich's reagent as modified by Mauzerall \& Granick (1956). The media from three cultures gave a pink colour, indicating that they accumulated a substance having a pyrrole or indole ring. The parental strain POPA1 did not give a coloured product with the reagent. The new mutant strains were designated SEC200, SEC203 and SEC206.

Other pyrroles, as well as PBG, form pink compounds with Ehrlich's reagent, and it was necessary to test whether the substance accumulated was PBG. To obtain pure samples, supernatant media from cultures of the three mutants were treated by the method of Cookson \& Rimington (1954) as described in Methods. The absorption spectra of the pink compound(s) formed on addition of modified Ehrlich's reagent were recorded between 700 and $380 \mathrm{~nm}$. The substance from each mutant gave the same spectrum as that obtained on addition of the reagent to an authentic sample of PBG (Sigma), with an absorption maximum at $555 \mathrm{~nm}$ and a lesser maximum at $325 \mathrm{~nm}$. The amounts of PBG accumulated are shown in Table 2.

More evidence that the accumulated substance was PBG came from chromatography, using the method of Westall (1952). Samples of the substances isolated from the supernatant media, and reference samples of PBG $(1 \mu \mathrm{g})$, were applied as spots in a line across the grain of $20 \times 20 \mathrm{~cm}$ duplicate sheets of Whatman no. 1 paper. The ascending method was used, at $18{ }^{\circ} \mathrm{C}$, and the solvent was butanol/glacial acetic acid/water (40:10:15, by vol.). When the solvent had traversed the sheets, one sheet was sprayed with Ehrlich's reagent to detect the spots. The second sheet was heated to $100{ }^{\circ} \mathrm{C}$ for $15 \mathrm{~min}$ in acetic 


\section{Table 2. Catalase activity and accumulation of porphobilinogen by mutant and parental bacteria}

For measurements of PBG accumulation, bacteria were grown for $24 \mathrm{~h}$ in $800 \mathrm{ml} \mathrm{GM}$, with shaking at 200 rev. $\mathrm{min}^{-1}$, and PBG was assayed by adding $2 \mathrm{ml}$ of modified Ehrlich's reagent to an equal volume of supernatant culture medium and measuring the absorption at $555 \mathrm{~nm}$ after $15 \mathrm{~min}$. For measurements of catalase activity, bacteria were grown aerobically for $17 \mathrm{~h}$ in $\mathrm{GM}$, resuspended in phosphate buffer $\left(0.01 \mathrm{M}, \mathrm{pH} \mathrm{6.8)}\right.$ to about $200 \mathrm{mg}$ wet wt $\mathrm{ml}^{-1}$ and assayed as described in Methods.

$\begin{array}{lc}\text { Strain } & \begin{array}{c}\text { in culture medium } \\ (\mu \mathrm{mol})\end{array} \\ \text { SEC200 } & 2 \cdot 9 \\ \text { SEC203 } & 1 \cdot 1 \\ \text { SEC206 } & 2 \cdot 7 \\ \text { POPA1 } & \text { ND } \\ \text { AB1621 } & \text { ND }\end{array}$

$10^{3} \times$
Catalase activity
$\left[\mathrm{l}(\mathrm{g} \text { dry wt) })^{-1} \mathrm{~s}^{-1}\right]$
$0 \cdot 3$
$0 \cdot 6$
$0 \cdot 5$
$4 \cdot 4$
$10 \cdot 1$

Dry weight of bacteria
[g (800 ml culture
medium $)^{-1}$ ]
0.43
0.49
0.44
0.92
0.98

ND, Not detectable $(<0 \cdot 1 \mu \mathrm{mol})$.

acid vapour to convert PBG to uroporphyrin, which was then detected under ultraviolet radiation at $380 \mathrm{~nm}$ as red fluorescent spots. The substance obtained from the mutants had the same $R_{F}$ as the reference sample of PBG and, like PBG, gave red fluorescent spots on heating in acetic acid vapour. The conversion to porphyrin by heating in acetic acid vapour is firm evidence that the substance was PBG (Falk, 1964).

\section{Indirect evidence that the mutants were deficient in haem}

The PBG-accumulating mutants grew very poorly with carbon and energy sources that K12 uses oxidatively but not fermentatively, such as lactate, succinate and acetate. The mutants grew more vigorously on fermentable substrates. Growth was not stimulated by haemin.

Beljanski \& Beljanski (1957) showed that haem-deficient mutants of $E$. coli had low catalase activity. The PBG-accumulating mutants had very low catalase activities (Table 2), suggesting that they were largely but not completely defective in haem biosynthesis.

\section{Evidence that strain SEC200 was deficient in porphobilinogen deaminase}

Assay of 5-ALA synthase showed that this activity was absent from SEC200 and its progenitors POPA1 and AB1621. On previous occasions, activity of the enzyme had been observed in POPA1 and AB1621 and the reason for lack of activity on this occasion is unexplained (see Discussion). Extracts of SEC200 possessed as much activity of 5-ALA dehydratase as extracts of parental bacteria, but had only one-tenth of the parental activity of PBG deaminase (Table 3 ).

Because substrates for some of the later reactions of haem biosynthesis were not available, the ability of extracts to convert PBG to uroporphyrin, coproporphyrin and protoporphyrin was assayed (see Methods). The results (Table 4) show that extracts of SEC200 formed smaller amounts of porphyrins than the progenitor strains, in agreement with the evidence that the mutant was relatively deficient in PBG deaminase. Ferrochelatase was not assayed: the mutant is partly deficient in ferrochelatase because of the hemGl(popAl) mutation which causes protoporphyrin accumulation (Cox \& Charles, 1973; and Table 4).

\section{Evidence that mutation hemC200 mapped between genes ilvD and metE}

Mutant allele hemC200, in SEC200, was mapped by conjugation and transduction. Mapping was laborious because the mutation was not conditionally lethal and it was not possible to select for hemC transconjugants. In two experiments, Hfr strains AB2575 and AB312 were used in uninterrupted conjugation with recipient SEC200 ara hemG1 gal rpsL 
Table 3. 5-Aminolaevulinate dehydratase activity and porphobilinogen deaminase activity in crude extracts of SEC200 and its progenitors

The same extracts were used for assays of both enzymes; assays were made in duplicate using different extracts. For details, see Methods. 5-ALA dehydratase activities are expressed as nmol PBG produced $\mathrm{h}^{-1}$ (mg protein $)^{-1}$, and PBG deaminase activities as nmol PBG consumed $\mathrm{h}^{-1}$ (mg protein) $)^{-1}$.

Strain Description of strain

AB1621

POPA1

SEC200

\author{
Mutant of AB1621 accumulating \\ protoporphyrin IX \\ Mutant of POPA1 accumulating PBG
}

Activity of
5-ALA
dehydratase
$9 \cdot 5$
$8 \cdot 0$
$8 \cdot 8$
$8 \cdot 3$
$8 \cdot 7$
$7 \cdot 9$

Activity of PBG deaminase $7 \cdot 6$

$5 \cdot 3$

$5 \cdot 8$

$5 \cdot 1$

$0 \cdot 3$

$0 \cdot 2$

Table 4. Conversion of porphobilinogen to porphyrins by crude extracts. of SEC200 and its progenitors

Extracts were assayed for the ability to form porphyrins from PBG as described in Methods. Results show the amounts of different porphyrins in the reaction mixture after 200 min incubation.

$\begin{array}{cccccc}\begin{array}{c}\text { Source of } \\ \text { extract }\end{array} & \begin{array}{c}\text { Amount of PBG } \\ \text { added (nmol) }\end{array} & \begin{array}{c}\text { Uroporphyrin } \\ (\mathrm{nmol})\end{array} & \begin{array}{c}\text { Coproporphyrin } \\ (\mathrm{nmol})\end{array} & \begin{array}{c}\text { Protoporphyrin } \\ (\mathrm{nmol})\end{array} & \begin{array}{c}\text { Protein } \\ (\mathrm{mg})\end{array} \\ \text { AB1621 } & 400 & 8 \cdot 4 & 14 \cdot 0 & 6 \cdot 6 & 22 \cdot 1 \\ & 0 & 0 & 0 & 0 & 21 \cdot 1 \\ \text { POPA1 } & 400 & 7 \cdot 0 & 18 \cdot 0 & 24 \cdot 0 & 18 \cdot 0 \\ & 0 & 0 \cdot 7 & 1 \cdot 6 & 14 \cdot 0 & 18 \cdot 9 \\ \text { SEC200 } & 400 & 2 \cdot 0 & 3 \cdot 5 & 1 \cdot 7 & 17 \cdot 6 \\ & 0 & 1 \cdot 1 & 2 \cdot 3 & 1 \cdot 2 & 17 \cdot 6 \\ \text { No extract } & 400 & 0 \cdot 4 & 0 & 0 & 0\end{array}$

$x y l$ hemC200. Selection was made for $\mathrm{rat}^{+}, \mathrm{gal}^{+}$and $x y l^{+}$transconjugants with the intention of classifying them as hemC200 and hem $\mathrm{C}^{+}$according to colony size and colour. Colony size proved to be unsatisfactory for this purpose because the colonies were often slimy and diffuse, especially on galactose minimal medium. One hundred colonies of each selected type, from each conjugation, were therefore restreaked and cultured separately in liquid minimal medium $(3 \mathrm{ml})$ of the same constitution as the selective medium from which they were picked, and the supernatant media were tested for PBG with Ehrlich's reagent. All the $\mathrm{ara}^{+}$and $\mathrm{gal}^{+}$recombinants accumulated PBG, but amongst the $\mathrm{xyl}^{+}$recombinants $68 \%$ (donor $\mathrm{AB} 2575$ ) and $97 \%$ (donor AB312) did not accumulate PBG, showing that hem $C$ was near $x y l$ at minute 80 .

Strains carrying hemC200 were used as donors in transduction, and selection was made for transduction of $x y l^{+}, r b s^{+}, i l v^{+}$and $m e t E^{+}$into appropriate recipients; 920 transductants were cultured separately and their supernatant media were tested for PBG. To check that transductants which were scored as hemC200 (Table 5) did indeed accumulate PBG and not other compounds which reacted with Ehrlich's reagent, one transductant of each of the classes $i l v D^{+}$hemC200, metE $E^{+}$hemC200 and rbs ${ }^{+}$hemC200 was grown separately in $800 \mathrm{ml} \mathrm{GM}$ containing the amino acids required for growth, and the compound accumulated was extracted and analysed as described above. All samples from the transductants were identical with a reference sample of PBG. A positive reaction with Ehrlich's reagent was therefore a satisfactory indicator of the hemC200 genotype. Table 5 shows that hemC200 was $6 \%, 24 \%$ and $40 \%$ cotransducible with $r b s^{+}, i l v D^{+}$and $m e t E^{+}$, respectively. The frequency of cotransduction of $i l v$ and metE depended on which marker was selected, as discussed by Bachmann et al. (1976). The data do not clearly point to a particular gene order. 
Table 5. Cotransduction of hemC200 with genes $r b s P^{+}, i l v D^{+}$and met $E^{+}$ The donors used were MLM200 ( $x y l^{+}$hemG1 hemC200) and SEC200 (hemG1 hemC200).

\begin{tabular}{|c|c|c|c|c|c|c|}
\hline Donor & $\begin{array}{l}\text { Recipient } \\
\text { and relevant } \\
\text { markers }\end{array}$ & $\begin{array}{l}\text { Selected } \\
\text { allele }\end{array}$ & $\begin{array}{c}\text { Trans- } \\
\text { ductants } \\
\text { per } 10^{7} \\
\text { phage }\end{array}$ & $\begin{array}{c}\text { No. } \\
\text { scored }\end{array}$ & $\begin{array}{l}\text { Unselected } \\
\text { donor } \\
\text { allele } \\
\text { present }\end{array}$ & $\begin{array}{c}\text { Cotrans- } \\
\text { duction } \\
\text { frequency } \\
(\%)\end{array}$ \\
\hline MLM200 & AB1621 $x y l$ & $x y l^{+}$ & 11 & 100 & hemC & 0 \\
\hline MLM200 & MLM509 met $E$ & $m^{+} t^{+}$ & 21 & 64 & hem C & 39 \\
\hline SEC200 & $\mathrm{AT} 716 r b s P$ & $r b s^{+}$ & 6 & 112 & hemC & 6 \\
\hline SEC200 & $\mathrm{AB} 2575$ ilv & $i l v^{+}$ & 14 & 48 & hemC & 25 \\
\hline \multirow[t]{2}{*}{ SEC200 } & MLM509 ilvD met $E$ & $i l v^{+}$ & 18 & 312 & hemC & 23 \\
\hline & & $\mathrm{met}^{+}$ & 20 & 284 & hemC & 38 \\
\hline \multirow[t]{5}{*}{ SEC200 } & MLM509 ilvD metE & $i l v^{+}$ & 18 & 200 & hemC & 17 \\
\hline & & & & & $\begin{array}{l}\text { met }^{+} \\
\text {hem } C \text { met }\end{array}$ & $\begin{array}{l}4 \\
8\end{array}$ \\
\hline & & $m e t^{+}$ & 20 & 200 & hem $C$ & 10 \\
\hline & & & & & ${ }_{i l v^{+}}$ & $\begin{array}{l}16 \\
32\end{array}$ \\
\hline & & ilv $v^{+}$et $^{+}$ & 8 & 80 & hem $C$ & 78 \\
\hline
\end{tabular}

At the start of the transduction experiments it was found that the supernatant media of AB3509 transductants always gave a pink product with Ehrlich's reagent, having an absorption maximum at $564 \mathrm{~nm}$ compared with $555 \mathrm{~nm}$ for the product of Ehrlich's reagent and PBG. Strain AB3509 required tryptophan, which apparently caused accumulation of a substance which reacted with Ehrlich's reagent. Tryptophan did not give a pink reaction with Ehrlich's reagent at the concentration present in the growth medium $\left(40 \mathrm{mg} \mathrm{1}^{-1}\right)$. The reactive substance may have been indole. To avoid the problem a $\operatorname{tr} p^{+}$transconjugant, MLM509 ilvD metE, of AB3509 was prepared and used in the transduction experiments.

\section{DISCUSSION}

Mapping showed that one of the mutations represented a new gene at minute 84 on the linkage map of Bachman et al. (1976). The gene was briefly mentioned by Powell et al. (1973) and given the temporary symbol popE, now superceded by the symbol hemC, which Săsărman et al. (1976) allotted to the gene for PBG deaminase. Haemin and porphyrins do not penetrate $E$. coli $\mathrm{K} 12$ bacteria under normal cultural conditions (Săsărman et al., 1968), and mutants which are fully defective in an enzyme of haem biosynthesis, such as PBG deaminase, are therefore likely to be inviable. Exceptions are mutants defective in the synthesis of 5-ALA, the first intermediate of the haem biosynthetic sequence; mutants responding to 5-ALA are well known, and they do not respond to haemin. The hemC mutants had about one-tenth of the PBG deaminase activity of their parental bacteria. This may explain why the mutants were able to grow slowly on glucose minimal medium and accumulate PBG. Mutants which accumulate PBG and have low or undetectable PBG deaminase have been described by Hatch \& Lascelles (1972) in Rhodopseudomonas, by Berek et al. (1974) in Bacillus and by Săsărman et al. (1976) in Salmonella.

A problem in the enzymological analysis was the failure to detect 5-ALA synthase activity in parental and mutant strains, even though it should have been present in all. On other occasions, activity of 5-ALA synthase has been detected in the parental strain AB1621 and in some haem-deficient mutants of K12 (Powell et al., 1973). The synthase is a difficult enzyme to assay, even in favourable organisms, and is especially difficult in $E$. coli; a better assay is needed than was available to us. The enzyme may be labile as in Rhodopseudomonas (Warnick \& Burnham, 1971) and may require a trisulphide activator (Davies et al., 1973). Presumably all the strains possessed 5-ALA synthase, because they did not require 5-ALA for growth. Taken together, the facts that hemC mutants accumulated PBG and had only 
$10 \%$ of the PBG deaminase activity of the parental bacteria provide evidence that the gene specifies $\mathrm{PBG}$ deaminase.

The gene hemC is typical of genes for haem biosynthesis in E. coli in mapping apart from other hem genes. In Bacillus subtilis (Anderson \& Ivánovics, 1967; Kiss et al., 1971; Berek et al., 1974) and Staphylococcus aureus (Tien \& White, 1968) the genes for haem biosynthesis tend to be closely grouped.

Selection for $i l v D^{+}$met $E^{+}$gave transductants of which $78 \%$ were hemC, suggesting that the gene order may be ilvD hemC metE, but better data are required to establish the order. In Salmonella typhimurium, mutations in a gene hemC similarly cause accumulation of PBG and map between genes $i l v$ and metE at minute 122 (Săsărman et al., 1976). The linkage map of K12 (Bachmann et al., 1976) shows 10 genes between $i l v$ and metE, five of which are of uncertain position. Finding the position of hemC amongst the other genes would be time-consuming using the methods described here. The isolation of mutants of K12 which are permeable to haemin (McConville \& Charles, 1975) has now greatly simplified genetical experiments with hem mutants and may simplify the mapping of the hemC gene. However, no mutants deficient in PBG deaminase were present amongst 55 haeminrequiring mutants isolated in a haemin-permeable strain (McConville, 1977).

This work was greatly aided by a Medical Research Council project grant to H. P. Charles, and by technical assistance from David L. Morris. The data in this paper are from the Ph.D. thesis of M. L. McConville (1977).

\section{REFERENCES}

Adelberg, E. A., Mandel, M. \& Chein Ching Chen, G. (1965). Optimal conditions for mutagenesis by $N$-methyl- $N^{\prime}$-nitro- $N$-nitrosoguanidine in Escherichia coli K-12. Biochemical and Biophysical Research Communications 18, 788-795.

ANDERson, T. J. \& IVÁNovics, G. (1967). Isolation and some characteristics of haemin dependent mutants of Bacillus subtilis. Journal of General Microbiology 49, 31-40.

BaCHMAN, B. J., Low, K. B. \& TAYLOR, A. L. (1976). Recalibrated linkage map of Escherichia coli K12. Bacteriological Reviews 40, 116-167.

BelJanski, M. \& Beljanski, M. (1957). Sur la formation d'enzymes respiratoires chez un mutant d'Escherichia coli streptomycine-resistant et auxotrophe pour l'hémine. Annales de l'Institut Pasteur 92, 396-412.

BereK, I., MiczaK, A. \& IvÁnovics, G. (1974). Mapping the $\delta$-aminolaevulinic acid dehydrase and porphobilinogen deaminase loci in Bacillus subtilis. Molecular and General Genetics 132, 233241.

Bogorad, L. (1958). The enzymatic synthesis of porphyrins from porphobilinogen. Journal of Biological Chemistry 233, 501-519.

Burnham, B. F. \& Lascelles, J. (1963). Control of porphyrin biosynthesis through a negative feedback mechanism. Biochemical Journal 87, 462472.

Cookson, G. H. \& Rimington, C. (1954). Porphobilinogen. Biochemical Journal 57, 476-484.

Cox, R. (1973). Studies on porphyrin-accumulating mutants of Escherichia coli. Ph.D. thesis, Reading University.

Cox, R. \& Charles, H. P. (1973). Porphyrinaccumulating mutants of Escherichia coli. Journal of Bacteriology 113, 122-132.
Davies, R. C., Gorchein, A., Neuberger, A., SANDY, J. D. \& TAIT, G. H. (1973). Biosynthesis of bacteriochlorophyll. Nature, London 245, 1519.

Doss, M. \& Philipp-Dormston, W. K. (1971). Porphyrin and heme biosynthesis from endogenous and exogenous $\delta$-aminolevulinic acid in Escherichia coli, Pseudomonas aeruginosa and Achromobacter metalcaligenes. Hoppe-Seyler's Zeitschrift für physiologische Chemie 352, 725733.

FALK, J. E. (1964). Porphyrins and Metalloporphy. rins. New York: American Elsevier.

Gibson, K. D., Laver, W. G. \& Neuberger, A. (1958). Initial stages in the biosynthesis of porphyrins. Biochemical Journal 70, 71-81.

HATCH, T. \& I.ASCELLES, J. (1972). Accumulation of porphobilinogen and other pyrroles by mutant and wild type Rhodopseudomonas spheroides: regulation by heme. Archives of Biochemistry and Biophysics 150, 147-153.

Herbert, D. (1955). Catalase from bacteria. Methods in Enzymology 2, 784- 788.

KISS, I., BEREK, I. \& IVÁNOVICS, G. (1971). Mapping the $\delta$-aminolaevulinic acid synthetase locus in Bacillus subtilis. Journal of General Microbiology 66, 153- 159.

Mauzerall, D. \& Granick, S. (1956). The occurrence and determination of $\delta$-aminolevulinic acid and porphobilinogen in urine. Journal of Biologicul Chemistry 219, 435-446.

MCConville, M.L. (1977). A study of mutants of Escherichia coli $\mathrm{K} 12$ defective in haem biosynthesis. Ph.D. thesis, Reading University.

McConville, M. L. \& Charles, H. P. (1975). Isolation of 'haemin-permeable' mutants and their use in the study of the genetics of haem 
biosynthesis in Escherichia coli K12. Proceedings of the Society for General Microbiology 3, 14-15.

Powel, K. A. (1975). Studies on the genetics and biochemistry of haem synthesis in Escherichia coli. $\mathrm{Ph} . \mathrm{D}$. thesis, Reading University.

Powell, K. A., Cox, R., McConville, M. L. \& Charles, H. P. (1973). Mutations affecting porphyrin biosynthesis in Escherichia coli. Enzyme 16, 65-73.

Săsărman, A., Surdeanu, M., Szegli, G., HorodNiceANu, T., Greceanu, V. \& Dumitrescu, A. (1968). Hemin-deficient mutants of Escherichia coli K12. Journal of Bacteriology 96, 570-572.

Săsărman, A., Chartrand, P., Proschek, R., Desrochers, H., Tardi, D. \& Lapointe, C. (1975). Uroporphyrin-accumulating mutants of Escherichia coli K-12. Journal of Bacteriology 124, 1205-1212.

Săsărman, A., Desrochers, M., Sonea, S., SANDERSON, K. E. \& SuRdeANu, M. (1976). Porphobilinogen-accumulating mutants of Salmonella typhimurium LT2. Journal of General Microbiology 94, 359-366.
TAYLOR, A. L. \& ADELBERG, E. A. (1960). Linkage analysis with very high frequency males of Escherichia coli. Genetics 45, 1233-1243.

TIEN, W. \& WhITE, D. C. (1968). Linear sequential arrangement of genes for the biosynthetic pathway of protoheme in Staphylococcus aureus. Proceedings of the National Academy of Sciences of the United States of America 61, 1392-1398.

VoGel, H. J. \& BoNNER, D. M. (1956). A convenient growth medium for Escherichia coli and some other micro-organisms (medium E). Microbial Genetics Bulletin 13, 43-44.

WARNICK, R. G. \& BURNHAM, B. F. (1971). Regulation of porphyrin biosynthesis. Purification and characterization of $\delta$-aminolevulinic acid synthetase. Journal of Biological Chemistry 246, 6880-6885.

WeChsLER, J. A. \& Adelberg, E. A. (1969). Antipolarity in the ilv operon of Escherichia coli K12. Journal of Bacteriology 98, 1179-1194.

WeSTALL, R. G. (1952). Isolation of porphobilinogen from the urine of a patient with acute porphyria. Nature, London 170, 614-616. 